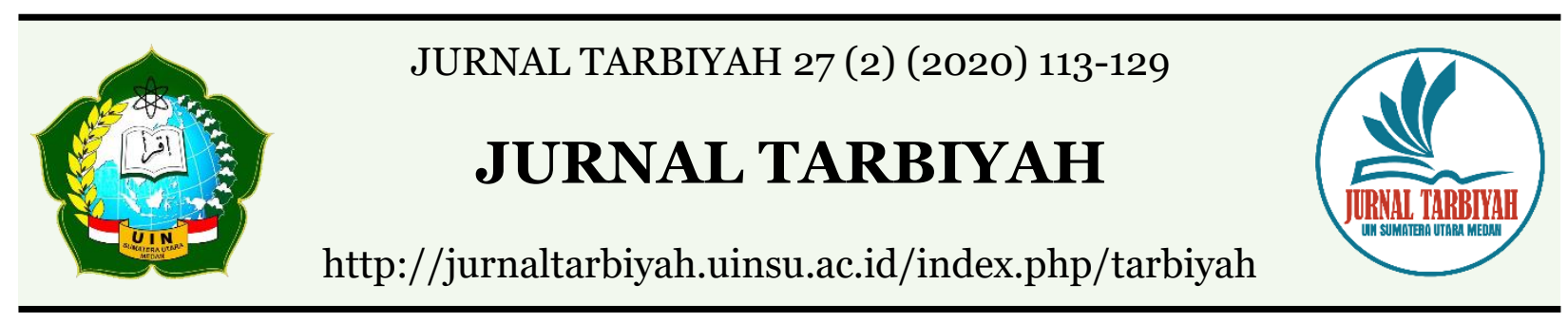

\title{
AMETTA LEARNING MODEL DESIGN (ACTIVE, FUN AND WITHOUT PRESSURE)
}

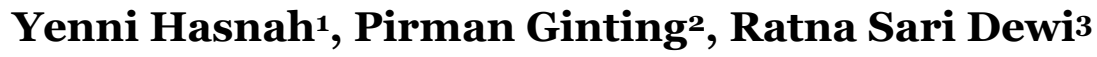 \\ 1,2,3 Muhammadiyah University of North Sumatra, Medan, Indonesia \\ Email: ${ }^{1}$ yennihasnah@umsu.ac.id, ${ }^{2}$ pirmanginting@umsu.ac.id, \\ 3 ratriwi2353@yahoo.co.id
}

DOI: 10.30829/tar.v27i2.773

Accepted: September 24th, 2020. Approved: December 25th, 2020. Published: December 31th, 2020

\begin{abstract}
This study aims to design a learning model that is active, fun, and without pressure called the AMETTA learning model. Research activities are carried out by applying a mixed research method that combines qualitative and quantitative data analysis with the stages of research activities, including literature studies, field studies, data collection, data analysis, and designing learning models. The results show that the AMETTA learning model design is suitable for use as a learning model to improve learning quality based on experts' feedback. This feasibility is also supported by an increase in the percentage of students' learning success, which is significant between the initial and final tests on smallscale (34.28\%) and large-scale (38.47\%) trials that this learning model is useful for implementation in learning activities. The AMETTA learning model meant is active, fun, and stress-free learning through the application of varied and exciting learning methods and media and the implementation of the Brain Gym in the learning process.
\end{abstract}

Keywords: design, AMETTA learning model 


\section{INTRODUCTION}

Learning is a vital element in producing quality education. As one of the actors in these learning activities, lecturers have a crucial role in creating quality learning. Quality learning will undoubtedly impact students' quality, both from the cognitive and affective aspects. Therefore, lecturers must create learning that is active, fun, and of course, without pressure. Learning conditions like this will form interactions in learning, both between lecturers and students and between fellow students themselves, positively and harmonious, and impact increasing students' interest in learning and their motivation to participate actively in every learning activity.

Learning is the result of the interaction of students, educators, and learning resources in a learning environment in producing quality learning processes and learning outcomes. In Law No. 20 of 2003 concerning the National Education System, article 1, verse 20 states that learning is the interaction of students with educators and learning resources in a learning environment. Meanwhile, Nur (2014) states that learning is an active interaction between teachers/lecturers who provides learning material with students/students as its object. The learning process is an activity in which there is a learning design system that causes an interaction between the speaker (educator) and the recipient of the material (students). With that, it can be concluded that learning integrates interactions between teachers, learners, and teaching materials that are realized in learning activities to achieve learning goals effectively and efficiently.

Quality learning must also be able to care for and develop student behavior for the better. Law Number 14 of 2005 concerning Teachers and Lecturers Article 6 states that the position of teachers and lecturers as professionals aims to implement the national education system and realize the goals of national education: developing the potential of students to become human beings who are loyal and devoted to God Almighty One, have a noble character, are healthy, knowledgeable, capable, creative, independent, and become democratic and responsible citizens. It is also under the demands of learning in the KKNI; namely, learning must prioritize creativity, capacity, personality, and student needs and be encouraged to have motivation within themselves, then strive to achieve the desired learning outcomes. Therefore, the learning paradigm that lecturer as the center of attention (lecturer-centered learning) changes to be (student-centered learning) so that a practical and conducive learning atmosphere is created to create behavioral changes and students' better competence. 
Nevertheless, in reality, this learning condition has not been realized adequately in Higher Education. It is because the applied learning has not been able to increase student activity and participation in learning activities. Educators (lecturers) still have an understanding (mindset) that considers lecturers to be the center of the role in achieving learning outcomes and seems to be the only source of knowledge so that it does not provide many opportunities for students to interact and get feedback on the material being studied. As a result, students are not independent; they are more dependent on lecturers' explanations. Besides that, this one-way learning also makes students less able to listen. It occurs as a result of dependence on broadcast materials and photocopies of questioning materials from lecturers. They feel at ease because broadcast material in the form of power points can be obtained from the lecturer (Higher Education Curriculum Book, 2014).

Another factor contributing to the creation of learning that is not conducive, and less quality is that students often get negative predicates that are not fun (bullying), such as stupid, lazy, who just cannot, and do not pay attention. This label lowers self-esteem and the enthusiasm of students to participate in the learning process actively. This condition is exacerbated by pressure or intimidation from educators when the peseta students (students) cannot attend lectures properly, such as a decrease in grades so that the students feel uncomfortable and comfortable. The results are that students feel bored, uncomfortable, and depressed.

Therefore, a creative effort is needed to design an innovative learning model, where students will be used as a learning center (student-centered learning) to become more active and creative in exploring their skills and knowledge more independently. Furthermore, this learning model will apply fun learning activities without any pressure (intimidation) for students. Therefore, this model can improve students' cognitive aspects and develop students' affective aspects (character). In connection with improving these two aspects, this research will produce an Active, Fun, and No Pressure learning model, called (AMETTA).

Active learning is a learning activity that emphasizes student learning experience. In other words, active learning makes students the center of learning so that students have independence in conducting experiments in development both in terms of skills and knowledge. Dzulfikri (2013) stated that Active learning is learning that invites students to learn actively. When students learn actively, it means that they dominate the learning activities. Furthermore, Subhan (2013) states that the active learning strategy is a 
teaching-learning method or strategy that shapes students' activity and participation as optimally as possible to change their behavior effectively and efficiently in their daily lives. Siahaan (2014) adds that active learning is intended to optimize all the potential students have to achieve satisfactory learning outcomes according to their characteristics. Also, active learning keeps students' attention so that they are focused on the learning process. From some of the statements above related to the concept of active learning, it can be concluded that active learning is a learning activity that keeps students and makes them the center of learning activities to learn more actively and be self-sufficient in order to achieve maximum learning outcomes.

Then, joyful learning is a learning process that is not boring, relaxed, and conducive, and there are various learning activities. Fun learning is creating an interaction relationship, both between educators and students and between fellow students themselves. Mulyasa (2007) states, "joyful instruction is a learning process in which there is a strong cohesion between educators and students, without feeling forced or depressed. Fun learning is a pattern of good relationships between teachers and students in the learning process. Teachers position themselves as student learning partners; even in some instances, it does not rule out teachers' possibility of learning from their students. In this case, it is necessary to create a democratic atmosphere, and there is no burden, both teachers and students in carrying out the learning process (Rusman, 2011).

The importance of fun learning in improving the quality of learning to produce maximum learning is also stated in Government Regulation No.19 article 19 paragraph 1, which states, "the learning process in academic units is held in an interactive, inspiring, fun, challenging, motivating students to participate, providing space actively and sufficient movement for the initiative, creativity, and independence according to talents, interests and physical development, as well as students' psychology. Thus, an educator must have skills in creating exciting learning for students. To produce enjoyable learning, an educator must design the learning, not from the educator's point of view but must be based on students' conditions and needs.

Furthermore, learning without pressure can be realized through good interaction between students and the environment so that there is a change in behavior for the better. In the context of the interaction between students and educators, a good educator must be able to create good communication for students to feel comfortable and relaxed. As a result, students can follow the learning process wholeheartedly without feeling depressed. 
Therefore, an educator no longer sees his students as machines, which is called behavioristic learning but must change it by applying humanistic learning, which views students as more human and respected as a whole.

In this lesson, Sanusi (2013) states that education's main task is to establish communication and personal relationships between individuals and individuals with groups in the school community. This relationship develops rapidly and produces educational fruits if it is based on the love between them. Individuals will only develop optimally and relatively without obstacles if they are in an atmosphere of love (unconditional love), an understanding heart, and practical (personal relationships ). From this viewpoint, it can be stated that an educator in educating their students must make them a complete individual who requires an increase in knowledge and can shape them into better-behaved individuals.

In this context, students are no longer viewed as subjects who are blamed by giving them negative labels, such as expressions of blaming, scolding, ridiculing, and even giving punishment (physical and value) for their low abilities or behavior that is not considered acceptable. This labeling and punishing resulted in an uncomfortable learning atmosphere. Students feel uncomfortable and pressured to participate in learning.

From some of the concepts planned in this AMETTA learning model, educators will position themselves as teachers to convey material only and as learning partners to be able to exchange information and knowledge so that a good interaction relationship between educators and students is built. This good relationship will contribute to creating a conducive learning atmosphere that impacts the development of a learning atmosphere that is relaxed, fun, and without feeling forced or depressed. Thus, this learning model will focus not only on the transfer of knowledge to learners but also on that, namely, the transfer of value.

The transfer of knowledge in question is often associated with the cognitive domain, learning outcomes related to intellectual abilities, or any brain activity efforts. This realm relates to the ability to think, including the ability to memorize, understand, apply, analyze, synthesize, and the ability to evaluate. According to Sudjana (2006), in the cognitive realm, there are six aspects or levels of the thought process, starting from the lowest level to the highest level, these six aspects include 1) Knowledge, which includes the memory of the things that are learned and stored in memory. 2) Comprehension refers to the ability to understand the meaning of the material. 3)Application refers to the ability to use or apply material that has been learned in new 
situations and involves the use of principles. 4) Analysis (Analysis) refers to the ability to decompose the material into relationships between one and another so that the structure and rules can be better understood. 5) Synthesis (Synthesis) refers to combining concepts or components to form a new structural pattern or form. 6) Evaluation (Evaluation) refers to the ability to consider material values for a specific purpose. Knowledge and understanding aspects are low-level cognitive, while aspects of the application, analysis, synthesis, and evaluation are high-level cognitive. The instrument that will be used in this research is a test. The test given is an essay test.

Transferring values is often associated with the affective domain, namely the realm related to attitudes and values. The affective domain includes behavioral characteristics such as feelings, interests, attitudes, emotions, and values. The characteristics of effective learning outcomes will appear to students in various behaviors, such as his attention to subjects, discipline in following subjects at school, his high motivation to know more about the lessons he received, and his appreciation or respect for teachers. The affective domain becomes more detailed into five levels: receiving, responding, valuing, organization, and characterization by evaluating or value complex. Sudjana (2006) The ability to receive (Receiving), refers to volunteerism and the ability to pay attention to appropriate stimulation responses. 2) Greeting (Responding), which is the attitude of students in providing active responses to stimuli that come from outside, including a willingness to pay attention actively and participate in an activity. 3) Appreciation (Valuing) refers to the assessment of the importance we attach to objects or reactions such as accepting, rejecting, or not considering. These goals can be classified into appreciative attitudes. 4) Organizing (Organizing) refers to the unification ofvalues as guidelines and guidelines in life. 5) Characteristics of value (Characterization by value), including the ability to live up to the values of life in such a way that they become personal property (internalization) and become a real and apparent guide in managing their life.

This research will design an active, fun, and stress-free learning model to improve students' affective and cognitive aspects based on the description above. Furthermore, this study's results can later be used as an alternative learning model to create an energetic, enjoyable, fun, and stress-free learning atmosphere to improve student learning achievement, manifested in good student learning outcomes. Besides, this learning model will also help shape students' personalities to become human characters, such as polite, disciplined, responsible, and independent. 


\section{METHOD}

This research is mixed research, which combines quantitative and qualitative data related to the AMETTA learning model's design.

\section{RESULTS AND DISCUSSION}

The learning model design in this study was carried out through several stages. The first stage is preparing a draft based on a theoretical study and an analysis of the model design requirements obtained during the preliminary study. Theory studies were carried out on the active and fun learning model. The results of the theory review and needs analysis are used as references in designing AMETTA learning models. Furthermore, a limited (small) trial was carried out followed by a revision of the test product on the scale, then continued with a more exhaustive (large) scale trial.

\section{Early Design Learning Model}

This study's learning model is a learning model that can produce active, fun, and carefree learning activities. Based on the theoretical study results and needs analysis carried out, a draft of the AMETTA learning model was produced with the following stages.

a. The teacher and students first carry out a Brain Gym (Brain Gym) before starting the learning process. This activity was preceded by drinking water, followed by brain exercises, and ended with a prayer. In reciting the prayer, it is advisable to enter Indonesian if the prayer is read in a particular religious language so that students can understand and absorb the meaning of the prayer. The prayer contents are also adjusted to the material and learning objectives to be achieved at that time.

b. Determine and design learning materials that are relevant to the conditions and needs of students.

c. Determine and apply a variety of learning methods to produce active learning, which is tailored to students' material and conditions.

d. Determine and apply learning tools or media to create exciting and fun learning activities.

e. Manage the class properly according to the needs of learning activities, such as seating arrangements (chairs or study tables)

f. Avoid giving negative feedback (demotivating feedback) both verbally and physically.

g. Evaluating the learning process and student abilities on an ongoing basis. 
After the AMETTA learning model draft is prepared, an expert judgment is carried out (expert validation). At this stage, the AMETTA learning model's design is submitted to the validator, namely an English Language Education lecturer with a doctoral degree, to be validated. He is also a Brain Gym trainer who has done much training on brain exercise (in improving the quality of learning. After being analyzed, the validator did not provide input because the draft learning model was considered excellent and ideal to be tested on a small scale.

\section{Small Scale Trial Results and Model Revisions}

Trials on a small scale were carried out to test the feasibility and feasibility of the learning model's initial design. The implementation of small-scale trials involves the lecturer and 11 students. Based on the AMETTA learning model's application on a limited scale, several aspects need to be revised to produce a better draft for the next trial.

In the early stages of implementation, the model lecturers and students did not fully understand the Brain Gym's implementation and the application of the learning model properly. It can be seen from the results of observing student activity during the learning process. Lecturers and students seem to have not mastered and are familiar with the Brain Gym movement, so that the learning implementation stages are not carried out following the objectives of implementing the learning model. Besides, the time allocation arrangements at each learning stage are also less than optimal so that the time allocation that has been prepared affects the implementation time of learning activities. Meanwhile, the arrangement of study chairs that do not provide enough space also results in brain exercise implementation not being carried out optimally. However, in general, learning activities are more active. Students are more enthusiastic and active during the learning process; students actively carry out discussions, share opinions in completing the learning material provided, and are eager to participate in the entire learning process without feeling the pressure.

Based on the reflection on the implementation of the small-scale field test of the AMETTA learning model, it can be concluded that there are some right parts and some things that need to be revised. The results of reflection include: (a) related to the implementation of the Brain Gym movement, it is very necessary to show the stages of the Brain Gym movement to students and practice it more often so that they become accustomed to it, (b) the study chairs have been well managed, but need to pay attention to the availability of space (space) which is sufficient in implementing the Brain Gym movement, (c) time allocation at each learning stage needs to be better managed, (d) the 
learning media used are good, but lecturers need to be more active in controlling media use, especially when using cellular phones as a learning medium, (e) learning activities are suitable, but lecturers are still rigid in implementing each series of learning methods applied, (f) student activities during the learning process are good, but lecturers need to monitor and control student learning activities so that learning remains in accordance with established procedures, and ( $\mathrm{g}$ ) selection $\mathrm{m}$ The learning material has been good, but it needs to be linked to the real conditions of students so that they can easily understand and enthusiastically follow the teaching material.

Furthermore, the level of effectiveness of implementing the AMETTA learning model in small groups can also be seen in the percentage of student success rates, as shown in the following table.

Table 5.1 Percentage of Student Success Rate in Small Group Trial Stage

\begin{tabular}{llll}
\hline \multirow{2}{*}{ Number of Students } & \multicolumn{2}{l}{ Successful Percentage } & Improvement \\
\cline { 2 - 3 } & Pre-test & Post-test & \\
\hline 11 & $36,36 \%$ & $70,64 \%$ & $34,28 \%$ \\
\hline
\end{tabular}

The data in the table above shows that the AMETTA model's application has improved student learning abilities, which reached $34.28 \%$, from $36.36 \%$ in the pre-test and $70.64 \%$ in the post-test.

The findings obtained during the limited-scale trial implementation process are reported to expert judgment. From the findings of these problems, expert validators considered it necessary to revise the AMETTA learning model's design. The following are some of the revised results from the expert judgment:

1) The applied learning method steps must be arranged regularly and written in a short and easy to understand manner.

2) The stages of the Brain Gym movement are sequenced, and their implementation is clearly explained.

3) The seating arrangement for students is arranged by providing sufficient space for students to carry out the Brain Gym movement, both during group and individual learning implementation.

4) The time allocation for each learning stage must be determined proportionally so that all learning steps can be carried out correctly. 
5) The use of learning media is adjusted to the needs of learning and is under the lecturer's supervision.

After obtaining feedback from expert judgments, the researcher revised the draft AMETTA learning model based on input from expert validators. The draft AMETTA learning model after being revised is as follows.

a. The teacher and the students first carry out the Brain Gym before starting the learning process. This activity was preceded by drinking water, followed by brain exercises, and ended with a prayer. In the Brain Gym implementation, lecturers must pay attention to the arrangement of student seats that provide sufficient distance to carry out the Brain Gym not to disturb others. Meanwhile, the recitation of prayer is recommended to include Indonesian if the prayer is read in a particular religious language so that students can understand and absorb the meaning of the prayer. The prayer contents are also adjusted to the material and learning objectives to be achieved at that time.

b. Applying various learning methods is to produce active learning, which is tailored to students' material and conditions. Learning methods and steps are directed to encourage students to take an active role at every learning process stage. Meanwhile, the lecturer acts as a facilitator.

c. Using learning tools or media is to create exciting and fun learning activities.

d. Delivering and exploring learning material that is relevant to the conditions and needs of students. Lecturers need to consider the alignment of teaching material with the life context of students.

e. Manage the class properly according to the needs of learning activities, for example, in the seating arrangement according to the needs of the learning methods that are applied and arranged so that they do not interfere with learning activities, especially during the implementation of the Brain Gym.

f. Avoid giving negative feedback (demotivating feedback) both verbally and physically.

g. Providing opportunities for students both in groups and individually to explore their competencies.

h. Evaluating the learning process and student abilities on an ongoing basis.

After revisions were made to the stages of implementing the learning model, the research activity was continued with trials on a large scale. 


\section{Large Scale Trial Results and Model Revisions}

The AMETTA learning model design trial was conducted in a classroom with a total of 39 students. This trial aims to improve the draft learning model that has been applied in previous trials. Based on the results of reflection on large-scale trials, several parts need to be maintained and improved for improvement, which is described as follows.

a. Class management is getting better. The arrangement of student study chairs has been arranged according to the needs of learning activities.

b. Determination of time allocation and implementation has gone quite well.

c. Learning media are right and can be used according to learning needs. However, there needs to be a firmer emphasis from the lecturers regarding the rules for using learning media, especially smartphones.

d. Student activities in learning activities are getting better. Students are very enthusiastic and enthusiastic both in discussion activities and in expressing their responses. However, the teacher's role as manager and facilitator must be further strengthened so that it can better manage the class, control student learning activities, and facilitate students in the learning process.

e. The lecturer activity during teaching is quite good. Lecturers can manage learning according to the steps or stages of learning activities that have been prepared.

f. When learning is carried out in groups, the division of the groups is not evenly distributed. It can be seen from the activity of students in groups that are less active as a whole.

g. At the end of the lesson, the lecturer and students do not make conclusions about the teaching material together.

Then, the effectiveness of applying the AMETTA learning model in large groups can also be seen from the increase in the percentage of student success as described in the table below.

Table 5.2 Percentage of Student Success Rate in Large Group Trial Stage

\begin{tabular}{llll}
\hline \multirow{2}{*}{ Number of Students } & \multicolumn{2}{l}{ Successful Percentage } & \multirow{2}{*}{ Improvement } \\
\cline { 2 - 3 } & Pre-test & Post-test & \\
\hline 39 & $46,15 \%$ & $84,62 \%$ & $38,47 \%$ \\
\hline
\end{tabular}


Based on the results of the pre-test and post-test obtained from large-scale trials, it can be seen that there is a significant increase in student learning success through the application of the AMETTA learning model. The increase rate was $38.47 \%$ between the pre-test and the percentage of student success of $46.15 \%$ and the post-test to $84.62 \%$.

After carrying out a wide-scale trial, the reflections on the findings obtained during the trial process were discussed with expert validators. From the results of the discussion, there were several inputs as material for revisions to improve the model design, namely:

a. Topics and learning objectives should be conveyed before the Brain Gym activity begins. It is necessary to absorb and internalize it during the implementation of brain exercises and recitation of prayers.

b. Brain exercise movements must be followed by vigorously and earnestly.

c. Study groups must be divided evenly heterogeneously, for example, by gender and students' level of ability if the learning method applied requires study groups.

d. Lecturers and students together provide conclusions/summaries and affirmation of the teaching material being studied.

From the large-scale trial's revised results, a recommended model was created, which is as follows. The Active, Fun, and No-Pressure Learning Model (AMETTA) is a student-centered learning model, where they play a more active role in each stage of learning. This learning can arouse students' interest in learning so that learning objectives can be adequately achieved.

The AMETTA learning model is characterized by being fun and stress-free. Fun learning, namely learning activities that are relaxed, not boring, and varied, can arouse enthusiasm and a strong desire for students to participate in the learning process. In the learning process, the teacher acts as a learning partner to create a harmonious relationship between educators and students without compulsion. Without pressure, good communication is created so that students feel comfortable following the learning process. Students are not treated as subjects who receive adverse treatment at the learning stage, such as scolding, criticizing, and physically punishing and threatening their value for their inability to understand the learning material. Negative labeling will severely impact students' discomfort and feeling of pressure in participating in learning. Furthermore, the steps for the AMETTA learning model can be described as follows. 
a. Educators first convey the topics and learning objectives to be achieved.

b. Educators, together with students, do Brain Gym before learning activities begin. This activity was preceded by drinking water, followed by brain exercises, and ended with a prayer. In the implementation of the Brain Gym, educators must pay attention to students' seating arrangement by providing sufficient space so that they can carry out Brain Gym movements freely. Meanwhile, the prayer's recitation is recommended to include Indonesian if the prayer is read in a specific religious teaching language to understand and absorb the meaning of the prayer delivered. The prayer contents are also associated with the material and learning objectives to be achieved at that time.

c. Applying a variety of learning methods to produce active learning, which is tailored to students' material and conditions. Learning methods and steps are directed to encourage students to take an active role at every learning process stage. Meanwhile, educators act as facilitators. Educators facilitate students in implementing the learning process.

d. Make use of learning tools or media to create exciting and fun learning activities.

e. Delivering and exploring learning material that is relevant to the conditions and needs of students. Educators need to consider the alignment of teaching materials with the context of students' lives.

f. Manage the class well according to the needs of the learning method. For example, seating arrangements that support the implementation of the learning method being applied.

g. Avoid giving negative feedback (demotivating feedback) both verbally and nonverbally. If students experience difficulties and make mistakes, they avoid using disparaging and mocking words and punishment. On the other hand, educators must provide responses that can build students' enthusiasm for learning.

h. Educators, together with students, make summaries / conclude learning material.

i. Evaluating the learning process and the abilities of students on an ongoing basis. 
Concerning the second step in implementing the AMETTA Model above, the following describes the Brayn Gym concept. Brain Gym introduced by Dennison (2008), consists of 26 movements which are divided into three main movement parts that are useful for activating the three dimensions of the brain; The Laterality Dimension (stimulate), the Focusing Dimension (lighten), and the Centering Dimension (relax). The three main movements/dimensions include the following movements: (1) Midline Movements, (2) Lingering Activities, (3) Energy Exercises, and (4) Deepening Attitudes.

Midline Movements have movements: (a) cross crawl, (b) figure 8 sleep (lazy 8's), (c) double doodle, (d) figure 8, (e) elephant (the elephant), (f) neck rolls, (g) the rocker, (h) belly breathing, (i) cross crawl sit-ups, and (j) filling energy (energizer).

Brain Gym movements in Lengthening Activities include: (a) an owl (the owl), (b) activating the arm (arm activation), (c) swinging the leg (footlex), (d) calf pump, (e) gravity glider, and (f) the grounder.

Energy Exercises include: (a) drinking water, (b) brain buttons, (c) earth buttons, (d) balance buttons (e) space buttons, (f) energy yawn, and (g) thinking cap. Furthermore, deepening attitudes only have two types of movement, namely hook-ups and positive points.

Demuth (2005) suggests that the Brain Gym implementation should be preceded by several PACE activities (Positive, Active, Clear, and Energetic). Energetic (drinking water) is sufficient (0.3-0.4 liters / $10 \mathrm{~kg}$ body weight) to increase the flow process between all brain and central nervous activity with the five sense organs. Brain ButtonClear (brain switch) aims to clear the brain by massaging the brain switch area (soft tissue under the collarbone on the left and right of the sternum). The massage is done by placing one hand on the point of two fingers under the collarbone, while the other hand is placed on the navel while rubbing it. Active is a cross-movement (cross crawl) by moving the right hand simultaneously with the left leg or vice versa, which has a function to smooth the circulation of brain fluids so that it can balance the flow of information in the brain and coordinate the information system between the brain and body. A positive energy movement aims to connect all environments of the body's bioelectric functions so that mental and physical relief is maintained. Movements can be performed in a sitting, standing, or lying position by crossing legs and extending hands with thumbs down, fingers of two hands crossed, hands turned downwards, and pulled up in front of the chest. Close your eyes and take a deep, relaxed breath for 1-2 minutes. When inhaling, the tongue is attached to the mouth's roof about $1 \mathrm{~cm}$ behind the teeth or on the part that was 
touched when pronouncing the letter ' $\mathrm{D}$ '. On exhaling through the mouth, the tongue is released again.

The AMETTA learning model's superiority is basically reflected in the learning concept itself, namely active, fun, and stress-free learning. Here are some of the advantages of the AMETTA learning model:

a. Implementing the Brain Gym movement can help maintain the freshness of the brain, constriction, and stable emotional sensitivity of students.

b. Helping to foster the independent thinking of students.

c. Train students to think and absorb learning quickly.

d. Students are motivated to participate in learning activities actively because of various learning methods and media.

e. Learners are actively involved comprehensively, both physically, mentally, and emotionally.

f. Build students' self-confidence.

g. Build mutual respect, both between students and students with educators.

h. A harmonious relationship or interaction is built between fellow students and students and educators.

i. On the other hand, the AMETTA learning model also has weaknesses, including:

j. Requires the creativity of educators in creating activities and utilizing various learning media.

k. Requires more money because it uses various learning media.

1. Lecturers will experience difficulties in managing the class when applied to large classes.

\section{CONCLUSION}

The results showed that the AMETTA learning model (Active, Fun, and Without Stress) was appropriate to be used as a learning model in improving the quality of learning based on feedback provided by experts. This feasibility is also supported by increasing students' learning success percentage, which is significant between the pre-test and posttest on small-scale (34.28\%) and large-scale (38.47\%) trials, which indicates that this learning model is useful for implementation. in learning activities. The AMETTA learning model meant active, fun, and stress-free learning by applying varied and exciting learning methods and media, such as implementing the Brain Gym in the learning process. 
The AMETTA learning model is a learning model that can be applied in learning activities to produce a quality learning process. Therefore, in applying this learning model, teachers must think actively and creatively to produce vigorous and exciting learning activities. A teacher is required to prepare the aspects needed in learning, such as the design of varied learning activities, the use of exciting learning media, and the determination of contextual learning materials. To improve the quality of learning, this learning model can be further developed to produce a learning model to overcome various learning obstacles.

\section{REFERENCES}

Demuth, E. 2005. Meningkatkan potensi belajar melalui gerakan dan sentuhan: sebuah pengantar dan pedoman dasar "Edu-k" dan "Brain Gym". Jakarta: INT.

Denninson, P.E. \& Denninson G.E. 2008. Brain Gym 101: Balance for Daily Life. Ventura, CA: Edu-Kinesthetics, Inc.

Direktorat Pembelajaran dan Kemahasiswaan, Direktorat Jenderal Pendidikan Tinggi dan Kementerian Pendidikan dan Kebudayaan. 2014. Buku Kurikulum Pendidikan Tinggi.

Dzulfikri, J.M. 2013. Pembelajaran Reconnecting terhadap Hasil Belajar Siswa pada Mata Pelajaran Menggunakan Hasil Pengukuran Kelas XI TITL Semester I di SMKN 7 Surabaya. Jurnal Pendidikan Teknik Elektro, Volume 2 Nomor 2, Tahun 2013, 515-522.

Mulyasa, E., 2007. Standar Kompetensi dan Sertifikasi Guru. Bandung. PT Rosdakarya. Nur, Gina Dewi Lestari. 2014. Pembelajaran Vokal Grup Dalam Kegiatan Pembelajaran

Diri di SMPN 1 Panumbangan Ciamis. (skripsi). Universitas Pendidikan Indonesia. repository.upi.edu. perpustakaan.upi.edu.

Rusman. 2011, Model-Model Pembelajaran. Jakarta: Rajawali Pers.

Sanusi, Uci. 2013. Pembelajaran dengan Pendekatan Humanistic (Penelitian pada MTs Negeri Model Cigugur Kuningan. Jurnal Pendidikan Agama Islam- Ta’lim. Vol.11 No.2. Hal. 23-42.

Siahaan, F.B. 2014. Pengaruh Model Pembelajaran Aktif Tipe Quiz Team terhadap Kemampuan Pemecahan Masalah Matematika. Jurnal Suluh Pendidikan FKIPUHN Volume 1 (1), 34-45, September 2014. ISSN: 2356-2595. 
Yenni Hasnah, Pirman Ginting, Ratna Sari Dewi / JURNAL TARBIYAH 27 (2) (2020) 113-129

Subhan, A. 2013. Penerapan Strategi Belajar Aktif (Active Learning Strategy) dalam Pembelajaran Pendidikan Agama Islam di SD Islam Nurul Hidayah. Skripsi: Pendidikan Agama Islam Fakultas Ilmu Tarbiyah dan Keguruan Universitas Islam Negeri Syarif Hidayatullah Jakarta.

Sudjana, Nana. 2006. Penilaian Hasil Proses Belajar Mengajar. Bandung: PT. Remaja Rosdakarya.

Undang-Undang Nomor 20 Tahun 2003 tentang Sistem Pendidikan Nasional.

Undang-Undang Nomor 14 Tahun 2005 tentang Guru dan Dosen. 